\title{
A Community Portnership Programme Addresses the Needs of Three Partners in a Unique Way
}

\author{
M.J. Viljoen \\ Ph.D.
}

School of Nursing

University of the Orange Free State

\&

\section{K.C. Househam}

M.D.

Department of Health

Free State

$\&$

\section{S.J. Wessels}

Ph. D.

Mangaung-University of the Orange

Free State Community Partnership Programme

University of the Orange Free State

\section{Opsomming}

Die proses vir die daarstelling van ' $n$ gemeenskapsontwikkelingsprogram tussen drie vennote, te wete die gemeenskap van Mangaung, die Universiteit van die Oranje-Vrystaat en die Departement van Gesondheid van die Vrystaat word van meet af aan bespreek. Die fases van die proses, die verbandhoudende struikelblokke, die redes vir sukses, die omvang wat die program aangeneem het, sowel as die mate waarin die drie vennote daarby gebaat het, word uitgewys.

\section{Introduction}

In order to develop a strong and powerful South Africa, it is very important that we develop strong and powerful communities, partnerships and regions.

The concept of community development in health programmes emerged from the 1978 Alma Ata Declaration of primary health-care. The declaration projected community involvement as the pivot upon which the success of the primary health-care approach to health-care delivery rests (Chimere-Dan, 1996). This Declaration provided the world with ethical precepts, political imperatives and technical direction. What was not given was the conceptual framework and policy guidelines on how community development in health programmes would operate.

The University of the Orange Free State was also faced with this dilemma when a call for proposals for funding of community development/partnerships programmes was announced by the W.K. Kellogg Foundation in 1991. The Foundation placed a high priority on the establishment of innovative, comprehensive, affordable primary care oriented health-care centres. The assumption was made that this long-term strategy depends on partnerships between institutions and communities that will adapt health personnel education to better prepare personnel for delivering such services. "The absence of academic, com-

\section{Abstract}

The process for the establishment of a community development programme between three partners, namely the community of Mangaung, the University of the Orange Free State and the Health Department of the Free State is discussed from the beginning. The phases of the process, the related stumbling blocks, the reasons for success, the scope of the programme, as well as the extent to which the three partners benefited from it, are discussed.

munity-based, primary health-care centres which can integrate the functions of care, research and teaching and that would balance the excellent tertiary-oriented models which already exist" was stated as an overriding problem by the Foundation.

Related to the abovementioned sentiments, but at a later stage, the White Paper on Higher Education (1997) summarized the transformation of higher education in the country as:

- $\quad$ increased and broadened participation;

- $\quad$ responsiveness to social interests and needs; and

- cooperation and partnerships in governance.

According to the Fina: Report on Community Service in Higher Education (1998) the benefit yielded by community service programmes in higher education depends on the following factors:

- The articulation between the programmes and the curricula with which they are associated.

- The orientation of leadership in the higher education institution towards being more socially responsive through teaching and research.
The extent to which the 
programmes provide a site for the realization of teaching and research goals.

Programme design and manage ment.

Although the abovementioned educational approaches were not comprehended to the same extent in the early ninenties, the academic staff of the then Faculty of Medicine (Faculty of Health Sciences since 1997) and Faculty of Social Sciences of the University of the Orange Free State were keen to become involved in an initiative that could address the shortcomings in health-care delivery, as well as the education of health-care professionals. To this effect the development of the Mangaung-University of the Orange Free State Community Partnership Programme (MUCPP) was envisaged.

With hindsight on the progress made, it becomes clear that the initiatives of the University in the early nineties related closely to the determining factors of benefit to partners.

\section{Partner-related Problem Statement}

The Free State is the central inland province of the Republic of South Africa with Bloemfontein/Mangaung as the provincial capital with an estimated population of 300000 people in 1991. As a consequence of the historical development of Bloemfontein and the policy of apartheid, most of the black population lived in Mangaung, a geographically separate area adjacent to Bloemfontein. The name Mangaung means "the lair of the leopard." The town has been in existence since 1861 and is the largest and closest residential area for black people who had a significantly lower standard of living than the majority of the white population then living in Bloemfontein.

The lack of appropriate infrastructure in Mangaung together with a lack of provision of adequate basic health and primary health-care services, created a situation in which a very high percentage of patients in need of even very basic health-care services utilised the services of a tertiary referral teaching hospital. In addition to the relative unavailability of appropriate primary health-care facilities, research also indicated that the perception of the community generally was negative, particularly with regard to accessibility of services as well as the sensitivity of staff to the health-care needs of patients (Pretorius 1991). Rapid urbanisation took place after the removal of regulations restricting the free movement of black people. The resultant population influx and an increase in informal settlements in Mangaung created an increased demand for health-care services.

The policy of the local Universtiy of the Orange Free State excluded black students until the late eighties. In addition to this restriction the language of tuition until 1993 was predominantly Afrikaans, which is the third language of most black students. Primarily for these reasons the University was not accessible to the community of Mangaung and its credibility was jeopardized. Besides these drawbacks most of the black candidates came from disadvantaged school backgrounds and were therefore not equipped to meet the selection criteria of the University.

The training of health-care professionals at the University was primarily hospital-based and students therefore had little exposure to primary health-care services to patients or to taking care of their total health-care needs.

Past policies also created a situation in which mutual understanding between race groups and communities was lacking. Academics and health professionals as well as disadvantaged communities therefore required development. The development of all role players was consequently crucial to support the philosophy of and to become involved in community partnerships and development.

The above disempowerment of the partners which resulted from the historical realities of South Africa was important when considering the possibility of a true partnership between the black community of Mangaung, the University and the health-care authorities responsible for the rendering of health-care services in the area.

\section{Programme Outline And Development}

The programme development was process-orientated including wide-ranging consultation with and involvement of the three partners, namely the academic staff of the University, the members of the community of Mangaung and the health authorities. Although the programme development is/was clearly phased it was apparent from the initial phase that the respective processes would follow the lines of horizontal strands and would be ongoing, and would therefore overlap. Evaluation of the programme and legal advice to the partners commenced during phase 2 and was ongoing thereafter. The five phases and aims of the programme were: PHASE 1 - Explora- tion; PHASE 2 - Building a partnership; PHASE 3 - Ensuring ownership and governance of the programme by the partners; PHASE 4 - Building of an infrastructure; and PHASE 5 - Operationalization, including development of portfolios coupled with the implementation of programmes.

The prinicples and values that were operative during the various developmental phases of the programme were: participation, representation, communication, sharing of information and responsibility, consultation, joint decision-making, identification of the tasks and roles of partners, and sharing in planning and implementation.

\section{PHASE 1 - Exploration, April 1991 to September 1991}

The programme was initiated in April 1991 when, at the invitation of the Kellogg Foundation, the academics of the Faculties of Medicine and Social Sciences were invited to a meeting by the Head of the Department of Pediatrics and Child Health at the University of the Orange Free State, to discuss the possibilities of a project proposal involving the University in rendering a primary healthcare service to an identified community. An Academic Workgroup was constituted and after a series of meetings a proposal was submitted at the end of May 1991. At this stage the input of the academics was dominant. The initial proposal was accepted, and seed funding was provided for developing the final proposal for full programme funding.

\section{PHASE 2 - Building a portnership, September 1991 < ongoing}

The community members and community leaders of Mangaung were invited to a series of meetings in order to participate in the project. The aims of a programme related to community empowerment and involvement were explained, discussed and debated at length. General mistrust of the community members dominated the course of the meetings. This was to be expected in view of the historical factors outlined above, and was an obstacle to be overcomed.

\section{Needs identification}

The purpose of community partnerships is to address problems/needs by making people more aware of the realities of the communities around them. The identification of the needs of the partners is not a one-off process. It is continuous since new needs are continually identi- 
fied as the programme develops. The initial needs assessment took place over a period of months and was characterised by a growing awareness of the mutual needs of the partners.

Needs of the community of Mangaung: A workshop was held in September 1991 with participants from 42 organisations in the Community of Mangaung, academics from the University and existing state structures, who identified healthcare and related needs in the community and prioritized them. This step taken at an early stage of the process was successful, spelt out direction and gave the beneficiary community the opportunity to state their case. In all probability such an opportunity in their community was highly exceptional, and they accepted it with enthusiasm.

The problems and needs identified by the workshops were as follows (prioritized): poverty and disempowerment; basic needs such as housing, roads, water, sewerage disposal and electricity; recreational facilities; social services for women, children and the aged; social problems such as teenage pregnancies and substance abuse; lack of early learning opportunities and school readiness and adult illiteracy; and unsatisfactory health services relating to the unavailablitty and inaccessibility of services and the insensitivity of healthcare personnel.

In addition to the needs identification workshops, a community profile was compiled early the next year. This was done by means of rapid assessment from existing resources as a significant amount of research had already been undertaken in Mangaung. Where the data was not generated by means of research or surveys, authoritative and knowledgeable persons in the community were consulted by means of interviews. This activity which involved members of several University departments and members of the Community Workgroup was a valuable activity for the extension and confirmation of the healthcare needs of the community, an opportunity to expand knowledge on the strengths and weaknesses of the larger community in the area, as well as an opportunity to enhance communication between groups and establish linkages with the community. In contrast to their attitude to previous research projects undertaken in the area, the community was enthusiastic and cooperative regarding the research effort.

At this stage it was apparent, in view of the disadvantaged nature of the community of Mangaung, that it would not be possible to engage the community in a programme that adressed only their health-care needs. As indicated, the community perceived their urgent needs to be wider and higher in priority than health-care.

Needs of the Academic Workgroup: The needs of the Academic Workgroup were never formally identified, but crystallized as the programme developed. It became clear that a need had developed to become involved in community development within the framework of the programme philosophy and that knowledge and understanding of the community of Mangaung was a necessity. As partners, academics were in need of development to enable them to adapt their management style to the bottom-up participatory approach. Academics also expressed a desire to become more involved in support programmes for black students which had already been instituted in certain departments of the University, and to adapt the training of health-care professionals to meet the health-care needs of the community.

Needs of the health-care professionals: The health professionals welcomed the opportunity to become partners and were extremely enthusiastic about becoming involved from the outset and about learning more about the community, the processes of community involvement and participation. This programme opened up avenues that were previously unknown to them and presented an opportunity to enhance the credibility of health-care delivery and to get communities involved in the promotion of their health. As was the case with the academics, they also felt the need to adapt their management style.

In this phase of the programme the needs identification for all the partners culminated in the setting of clear objectives for the programme by the partners eigthteen months after the first meeting was called:

- To establish an effective partnership between the community of Mangaung, the University of the Orange Free State and the health services in the area.

- To establish an effective primary health-care service for the community of Mangaung through intersectoral collaboration.

- To establish a community development programme for the community of Mangaung.

- To initiate affirmative action in the selection of students as well as to develop support programmes and bridging courses for disadvantaged students

- To promote community-based training for the health-care professionals at the University and to adapt educational strategies accordingly.

\section{Establishing}

\section{organizational structures}

Although an Academic Workgroup was constituted at the onset of the initiative, a need for liaison structures to drive and structure the process further and to represent other stakeholders had been felt since the onset. Arising from this, a steering committee was constituted with two lecturers of the Medical Faculty, one nursing lecturer from the Faculty of Social Sciences and two members from the community of Mangaung. The process was further structured when a Community Workgroup was constituted at the end of the first year, after several meetings with the community. Since its constitution this group has been meeting monthly, and serves as a means to provide the community with a platform to deliberate on all issues that affect the partnership and the community. Prior to the establishment of the Trust in October 1994, the business of the programme was handled by an acting director, the steering committee and the two workgroups.

During 1992 the MUCPP further developed an organizational structure and operationalized its activities by means of a series of working committees that remained responsible to the steering committee. A liaison committee was established between the University and the programme to facilitate decision-making and reporting. The appointment of community, training and health services coordinators as well as a secretary as permanent staff during this period was an important step to ensure the growth of the programme.

\section{Involvement, participation and partnership}

Although the community meetings were extremely well attended by the community and staff members of the health-care facilities in the area, the community initially responded cautiously to the concept of a partnership with the University. It was clear from the beginning that relationships of trust would have to be established prior to the establishment of partnerships. This process was slow and required a spirit of mutual respect and sensitization to the needs of the various partners. It was equally important to establish values such as commitment to a common task and ongoing commitment at all levels of community activity; sacrifice of individual interests if inconsistent with the ideals of the partners; sharing 
of a common vision leading to a contract and developing a common identity. This process had to be fostered and two successful workshops on community development and community partnerships, involving all partners, was held in the early stages of programme development.

Involvement and participation were also further strengthened by consultations with all University departments involved and regular meetings of the Academic Workgroup. The same strategy was followed for other community organizations and health-service providers in the area. Visits to other projects by the partners and attendance of workshops on partner-related issues by the members of the steering committee also proved to be very useful.

In these early phases it was already apparent that the involvement of the community of Mangaung would be one of the strong assets of the programme and that this commitment could become one of the major building blocks in its success. The strong element of community involvement built into this programme comes from the strong feelings that development and upliftment of the people is essential if the project is to succeed. It is a simple philosophy that puts power in the hands of ordinary people to enable them to control their own future and deal with their own problems. The group's negotiating skills and confidence in their own abilities have developed strongly. This was demonstrated when the community insisted on a logo for the programme, which with the vision statement of "HEALTH FOR ALL", was solely designed by the communty and approved for implementation by the other partners.

However, during this period concerns were expressed that a lack of transparancy and possible unknown factors might hamper progress. It was also felt that the community must be mobilized and should become a pressure group to advocate change and increase involvement of its members. Community members felt that they should be represented on the boards and structures of the University and that the influence and power of the educational institution should be directed to the needs of the community. The importance of communication and liaison, which includes the communication of information, good management and strategic planning, was also emphasized.

Although the health services have been enthusiastic in principle from the outset, the programme development went through a phase where community de- velopment and participation were fostered to such a degree that they (the health services) became marginalized to a certain extent. Uncertainty of the implications of the developments in the programme for their respective organizations could also have played a role. This was also true of the academics when members of the community became more and more involved in the development of the second proposal, which was submitted in July 1992 and approved for funding. During the development of the programme more funders came on board, and hence provided sustainablilty to the programme.

\section{PHASE 3 - Ensuring ownership and governance of the programme by the portners, July 1992 to November 1994}

During all stages of programme development it was assumed that significant control of the programme would rest with the community. The challenge was to create a structure that would not hamper the sensitivity of the process of programme development to the needs of the most vulnerable partners - those at grassroots level who use the service. This is extremely important, particularly for professionals who are inclined to implement strategies they regard as essential and logical and scientifically based. A pattern of relationships and a structured legal basis for the programme to ensure the autonomy, unique and separate identity, and local ownership of the programme had to be created. Several partner consultations with University legal advisers concluded that a trust would be a suitable legal entity for a community development programme.

The process of establishing a trust was an evolutionary and purposeful process characterized by wide consultation with the partners, and took 18 months. The first meeting of the Board of Trustees was held in October 1994, after the Trust Deed was registered with the Supreme Court. The Trust Deed was based on the fundamental operating philosophy that all its activities should be based upon shared decision-making, and in its operations it would comply with the following guiding principles: non-racialism, non-sexism, a sound developmental approach, improvement of the beneficiary community, equity, and at least $50 \%$ representation of the beneficiary community on all committees not otherwise designated in the Trust Deed.

The Trust functions under a Board of
Trustees which comprises 16 board members of whom 5 are University personnel, 3 health services members and 8 community members and a Management Committee which is equally represented by the three partners. Three forums (working groups) were constitutionally established where partners can discuss relevant issues and problems, namely the Community Working Group, the Academic Working Group and the Bloemfontein Health Services Forum. Other working and liasson committees were established according to needs.

Financial control of the programme rests with the Board of Trustees. The University undertook to ensure sound financial management of the funds.

The establishment of a pattern of relationships among partners is indicated in Figure 1. The matrix structure is a balanced compromise between functional and product organisation by superimposing a horizontal structure of authority, influence and communication on the vertical structure. In the arrangement shown, people assigned to the functional units on the vertical level not only belong to the functional unit, but also to a particular task group on the horizontal level. This kind of structure enables the units on the vertical level to utilize the services of specialists on the horizontal level, to adapt or respond to a rapidly changing and uncertain environment, to achieve optimum autonomy, and to communicate efficiently with one another.

With these organizational structures in place the steering committee which stood at the helm for three and a half years, was dissolved.

\section{PHASE 4 - Building an infrastructure - 1994 ongoing}

The serious lack of infrastructure in Mangaung made the building of a multipurpose community health centre at a strategically placed site in Mangaung imperative. It would house a primary health-care service component, a primary health-care training and development component, and a community resource centre. It has been decided to approach governmental as well as nongovern-mental sources for the funding of the centre. The University is also involved in other community-based research projects

A centre/building committee was set up to determine the architectural needs of the respective partners. The concepts of building and planning were explained to the partners at a successful workshop. In addition the students of the Depart- 


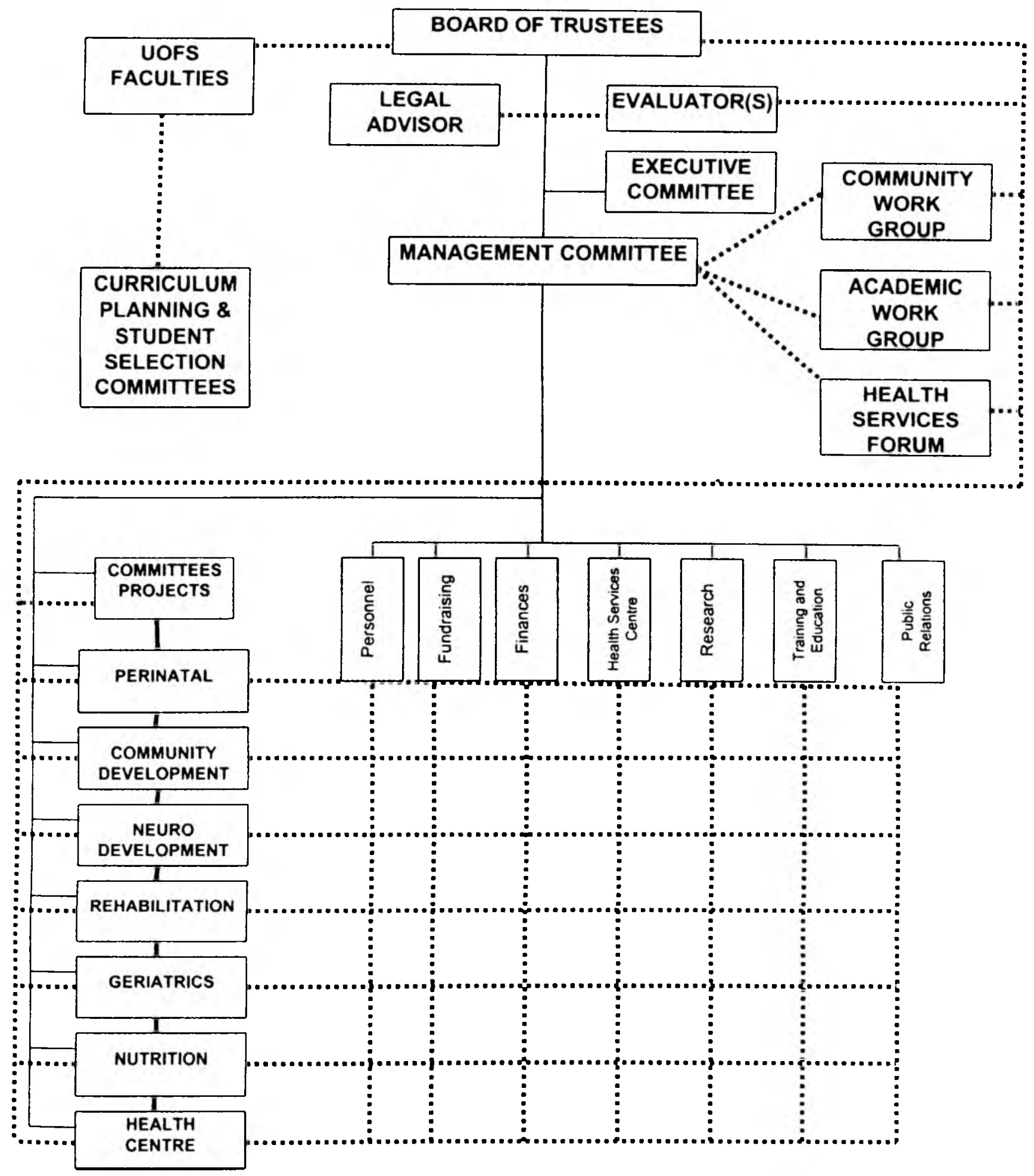

ment of Architecture of the University planned community centres for final-year assignments and submitted these to the partners as part of the process of becoming acquainted with the plannning and building process. The community participation in the planning of the centre was extremely enthusiastic and included visits to several successful and less successful centres. The process of planning and negotiating with governmental bodies took up to eighteen months, but was successful as regards partner involvement.
A matter that put the partnership to the test was the issue of ownership of the centre after the Provincial Administration undertook to build it. After a number of meetings, penetrating discussions and debating, the partners accepted that the Provincial Administration would retain ownership and that control of the centre would be vested in the Board of Trustees. This decision was a breakthrough in the attitude, nature and continuation of a true partnership and served as a watershed. This was also demonstrated by the Provincial Adminstration's agree- ment to appoint the architect chosen by the community.

Building of the multipurpose centre commenced early in 1997. In die interim phase temporary structures including offices, committee rooms, community hall and a kitchen had been erected on the site, whence the activities of the MUCPP, which were previously housed in the Medical Faculty of the University, are conducted. A temporary clinic was also erected on the site and was later expanded to a community health cen- 

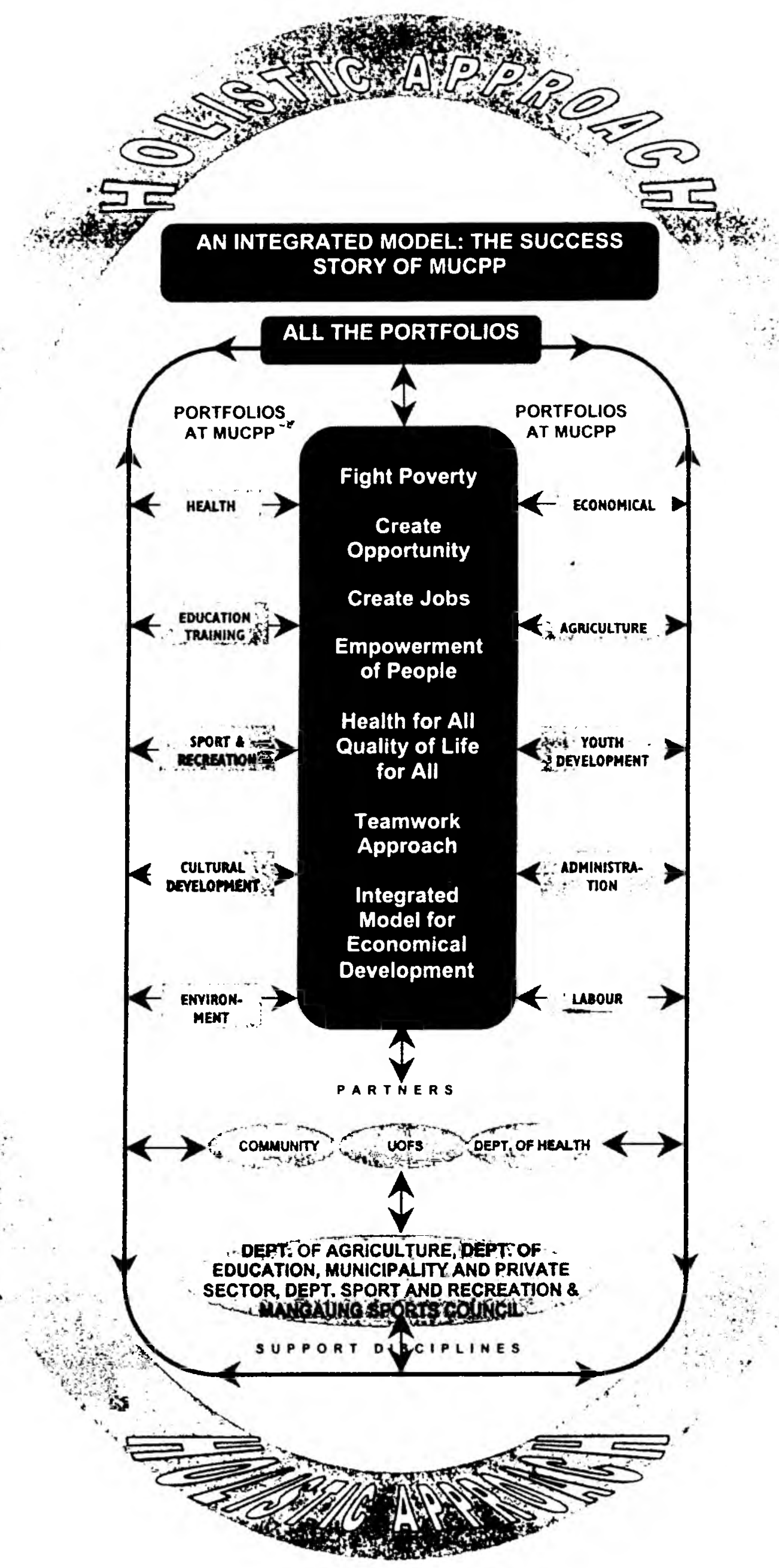
tre. These facilities were staffed by personnel of the Department of Health. Apart from these facilities, the physical presence of the MUCPP in the community is of crucial importance in order to maintain contact with the beneficiary community, to remain sensitive to their needs and to enhance their participation and involvement.

\section{PHASE 5 -}

\section{Operationalization,} including the development of portfolios coupled with the implementation of programmes - July 1994

\section{ongoing}

Putting plans into action commenced early in the programme, but progressed slowly as they were handicapped mainly by the energy absorbed by the essential process of structuring, as well as by the lack of infrastructure which had to be created first.

Eight staff members were appointed over a period of three years to assist and realize the implementation of the objectives of the Trust. The portfolios of the staff included community development, health services, education and training, youth development and administration. During this phase it was proven that a partnership could be managed with great success with the staff and the structures constituted through the Trust.

\section{Community development projects}

The aim of the various projects is to empower community people with skills and knowledge in order to create employment for themselves. This was done in a spirit of selfreliance, and in collaboration with a number of departments of the University and the Department of Trade and Industry where the necessary expertise was available and where clear commitment to become involved in community development was shown. These activities also provided an opportunity for intersectoral and interdisciplinary cooperation among departments. Examples of such projects are: neurodevelopment for preschool children; emergency care; perinatal exercises and care of mother and baby; treatment of minor ailments; health workshops for the youth; geriatric care; life-skills training; economic and small business skills development; training in entrepreneurial skills; coffin-making; welding; basic taxi service/car serv- ice skills; chicken-farming; food gardens and sewing and knitting club.

Through the community development programme, community members are also encouraged to participate in the various structures of the MUCPP, to attend workshops in the development of leadership skills, to learn how to conduct meetings and to learn about the roles of office bearers.

The idea of starting cultural development at the MUCPP was born out of the realization that the people's way of life influences their perception of the future as well as their personal development. After consultation with community members the MUCPP Youth Choir was established. Preparations are under way for starting an Afro-band.

The basic philosophy of rendering a health service to the community of Mangaung is that of a partnership between the health-care worker and the service recipients. The community was brought in as a partner through the structures of the MUCPP and the establishment of community health committees, which have now been formed through the different areas of Mangaung. The area committees determine the respective needs and problems of the areas involved, and have so far embarked on a number of projects, e.g. clean-up campaigns and assistance to the aged. The following subcommittees have been established through their involvement; Health Education, Traditional Health, Referrals, Perinatal Committee and the Committee for persons with disabilities in the community.

The Youth Forum of the MUCPP felt obliged to contribute constructively to the normalization to the education in the country. To this effect a Student Representative Course was instituted, which focused on the building and development of mature sound leaders amongst the youth. Other youth activities include workshops on relevant health problems amongst the youth, a speech contest and the development of entrepreneurial skills.

In 1996 a full-time Recreation and Sports Officer was appointed to facilitate the institution of a Sports and Recreation Development Programme. This programme is now offered at four different sport centres in Mangaung. The school children and community all benefit from the activities offered at these centres. Sport specialization is also done to mould identified talented players into possible national competitors.

\section{Education and training of University students and research}

Although some departments have already made curriculum changes in order to ensure more community-based training, the lack of clinical facilities in the community, and logistical problems were viewed as challenges.

A continuing education programmes for midwives, conducted through self-study modules in conjunction with skills workshops, commenced during 1994. Several departments commenced programmes on Video Supported Instruction in the same year to address the language problems of disadvantaged students.

The paradigm shift towards primary health-care, necessitated a change in educational strategy. The problembased teaching and learning strategy and community-based approach to education is advocated internationally as suitable to support the philosophy of primary health-care. This method was sucessfully implemented as a pilot survey at postgraduate level in 1995 and was instituted in the nursing undergraduate programme in 1997.

Since 1997, with the organized input of community members who operated through the health street committees, in collaboration with academic staff of the School of Nursing, first-year nursing students have been doing community profiles during the first-six months of their training, and spending the next eighteen months in community health settings. The Departments of Social Work, Occupational Health, Physiotherapy, Human Nutrition and the School of Medicine are planning and implementing a similar approach in the training of students.

Where appropriate, students and academic staff are also involved in the community development projects mentioned, and in rendering health-care services to the beneficiary community.

Selection criteria have been adapted to address the potential of disadvantaged students. Support programmes and supplemental instruction through the CAREER PREP PROGRAMME of the Academic Development Bureau of the University, the Educational Development Division of the Faculty of Health Sciences, as well as through academic departments, were introduced to give students the opportunity to develop to their full potential. In addition the University has adapted its language policy and parallel-medium instruction has been 
implemented to accommodate the language needs of non-Afrikaans speaking students. Bursaries are awarded to disadvantaged students to take care of their financial needs and encourage further development.

\section{International \\ collaboration and research}

A formal agreement of research collaboration and community development was signed by the MUCPP, Centre of Behavioural Sciences of the Department of Psychology of the UOFS and the Institute of Families in Society at the University of South Carolina in the USA. Through this agreement vital research information is exchanged and relevant community-based programmes are facilitated.

\section{Sustainability Through Continuing Evaluation}

During the first three years of the programme, external evaluation was done by a part-time University industrial sociologist, but this task was later taken over by national and international consultants, appointed by the respective donors of the programme. This process is ongoing.

The aim of the performance evaluation is to initiate and develop an evaluation process by means of which performance could be assessed and corrective actions could be taken. In this respect evaluation is not seen as the sole responsibility of the external evaluator, but should be seen as a process of selfevaluation and development, and the role of the evaluator in this regard as a facilitator of the process of evaluation. The phases and activities of the evaluation process consist of: Phase 1 - Ongoing data-gathering and establishing a criterion. (This includes the development of a conceptual model with special reference to elements of the management subsystem and organisation culture); Phase 2 - Performance appraisal and analysis; Phase 3 - Feedback to all stakeholders, elaboration by these groups, discussions and work on information; and Phase 4 - Correction such as action planning and action intervention (Fischer 1994).

\section{Concluding Remarks}

The programme was initiated during the socio-political transition in the country and proved to be congruent with the philosophy of the health-care policies of the new government which came into power in 1994. We therefore believe that the programme could be a model for partnerships and the planning of future health-care and other services. Although the needs of all the partners are being addressed to a greater or lesser degree as the programme progresses, the time is now ripe to pay more attention to them as the structure has been consolidated.

From this programme key messages for possible success which emerged were: early vision and understanding; addressing the real needs; assuring ongoing participation; involvement of all the stakeholders; ensuring sustainability of the programme through the implementation of realistic time frames and funding cycles; the integration of other educational institutions, fields and Departments at the UOFS as well as building upon identified strengths and assets of the respective partners. The use of an integrated model with a holistic approach, contributed to this success (see Figure 2).

Deriving from this, the MUCPP was nominated and elected Institute of the Year in 1996 by the Bloemfontein Publicity Association. Five other projects have also received honours.

The expansion of the programme on a subregional/regional basis remains an important challenge and opportunity in the future of the programme.

There is no doubt that institutions of higher education, such as the University of the Orange Free State, are well suited to play a major role in national and community service and should be committed to do so. In its mission statement the University of the Orange Free State emphasises community service and development through its core functions of education, research and the implementing of community developmental programmes. The MUCPP is one of our best examples of such and integrated service. 


\section{Bibliography}

ANSARI, W.E., 1998. Partnerships in health: How's it going to work. Target Issue, $1 \& 5$.

ANSARI, W.E., 1998. Partnerships in health: the pressing challenges. Public Health Forum, 5.

ANSARI, W.E., 1998. Tackling health issues at neighbourhood level - lessons from South Africa. Network News, 14-15.

BJÅRÄS, G, HAGLUND, B.J.A. \& RIFKIN, S.B. 1991. A new approach to community participation assessment. Health Promotion International, 6(3):199-206.

CHIMERE-DAN, G. C. 1996. Community involvement in urban health programmes. International Thompson Publishing (Southern Africa).

DE BEER, F. \& SWANEPOEL, H. 1996. Training for development. A manual for student trainers. International Thompson Publishing (Southern Africa).

FISCHER, E. 1994. MUCPP performance evaluation. Kellogg Foundation.

GRACE, H.K. 1990. Building community: A conceptual perspective. Perspectives, 20-22.

KASEJE, D.C.O. 1991. Community empowerment, the key to health for all. Namibian National Primary Healthcare Workshop, 16th to 28th February 1991.

MANGAUNG UNIVERSITY OF THE ORANGE FREE STATE COMMUNITY PARTNERSHIP PROGRAMME. 1997. Brochure, Graphcom Design Studio.

PEROLD, H.1998. Community Service in Higher Education. Joint Education Trust.

PRETORIUS, E., DE KLERK, G.W. \& VAN RENSBURG, H.C.J. 1991. Die tradisionele heler in die Suid-Afrikaanse gesondheidsorg. Pretoria: HSRC Report, HSRC.

RICHARDS, R.W., GRACE, H.K. \& HENRY, R.C. Community partnerships: A Kellogg initiative in health professions education. Community Partnerships with Health Professions Education, 1-26.

RIFKIN, S. \& CASSELS, A. 1990. Training managers for primary health-care: Teaching about community involvement. Medical Teacher, 12(1):39-45.

RIFKIN, S.B. 1986. Lessons from community participation in health programmes. Health Policy and Planning, 1(3): 240-249.

RIFKIN, S.B., MULLER, F. \& BICHMANN, W. 1988. Primary health-care: On measuring participation. Social Science Medical, 26(9):931-940.

SWANEPOEL, H. \& DE BEER, F. 1996. Communication for development. A guide for fieldworkers. International Thompson Publishing (Southern Africa).

SWANEPOEL, H. \& DE BEER, F. 1996. Community capacity building. A guide for fieldworkers and community leaders. International Thompson Publishing (Southern Africa).

TUMWINE, J.K. 1989. Community participation as myth or reality: A personal experience from Zimbabwe. Health Policy and Planning, 4(2):157-161.

VILJOEN, M.J., MULLER, M.E. \& UYS, L.R. 1990. Standaarde vir die maak van 'n gemeenskapsdiagnos 9. Curationis, 9-14.

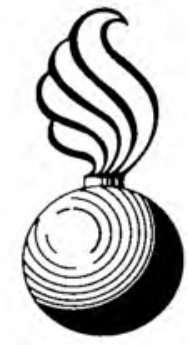

